Tersedia online di: http://ejournal-balitbang.kkp.go.id/index.php/jra

\title{
PERTUMBUHAN DAN VARIASI GENETIK IKAN BANDENG, Chanos chanos DARI PROVINSI ACEH, BALI, DAN GORONTALO, INDONESIA
}

\author{
Sari Budi Moria Sembiring", Gigih Setia Wibawa, Tony Setiadharma, dan Haryanti
}

Balai Besar Riset Budidaya Laut dan Penyuluhan Perikanan

(Naskah diterima: 28 November 2017; Revisi final: 2 Januari 2018; Disetujui publikasi: 2 Januari 2018)

\begin{abstract}
ABSTRAK
Ikan bandeng, Chanos chanos merupakan salah satu ikan ekonomis penting di Asia. Sejak tahun 1995, di Indonesia sebagian besar benih bandeng diproduksi dari hatchery sekitar Dusun Gondol, Bali Utara baik untuk pasar domestik maupun perdagangan internasional. Dalam rangka meningkatkan kualitas benih, perlu dilakukan perbaikan induk secara genetik menggunakan populasi yang unggul. Tujuan penelitian ini adalah mendapatkan data laju pertumbuhan dan variasi genetik induk ikan bandeng yang berasal dari lokasi perairan Aceh, Bali, dan Gorontalo. Pertumbuhan ikan bandeng diamati melalui pengukuran panjang dan bobot benih hingga ukuran $500 \mathrm{~g}$ (calon induk), serta variasi genetik diamati menggunakan metode RFLP DNA. Benih dan calon induk masing-masing dianalisis sebanyak 15 ekor. Hasil pengamatan pertumbuhan ikan bandeng mulai dari benih hingga menjadi calon induk, menunjukkan bahwa ikan bandeng dari Aceh dan Bali mempunyai pertumbuhan panjang dan bobot yang relatif lebih tinggi dibandingkan dengan ikan bandeng dari Gorontalo, walaupun secara statistik tidak berbeda nyata $(P<0,05)$. Hasil analisis variasi genetik terdapat lima komposit haplotipe dari empat enzim restriksi yaitu M bo I, HaellI, Hha I, dan Nla IV pada sekuens cytochrome-b. Jumlah rata-rata restriction site adalah 1-3 haplotipe. Populasi Aceh dan Bali memiliki nilai keragaman genetik yang lebih rendah $(0,080$ dan 0,000$)$ dibandingkan dengan calon induk dari benih Gorontalo $(0,115)$.
\end{abstract}

KATA KUNCl: genetik; pertumbuhan; bandeng; Chanos chanos; Indonesia

ABSTRACT: Growth and genetic variations of milkfish, Chanos chanos, from Aceh, Bali, and Gorontalo Province, Indonesia. By: Sari Budi Moria Sembiring, Gigih Setia Wibawa, Tony Setiadharma, and Haryanti

Milkfish, Chanos chanos is one of the economically important fish in Asia. Since 1995, milkfish seed mostly produced in Gondol area, Northern part of Bali, and suppleted both domestic and international markets. In order to improve its seed quality the improvement of milkfish broodstock genetic is required through selection of superior population. The aims of this research were to evaluate the growth performance and genetic variation of milkfish populations from Aceh, Bali, and Gorontalo Province. The length and weight of fry up to $500 \mathrm{~g}$ was measured as well as the genetic variation was detected using RFLP DNA method. Fry and young broodstock in the DNA analyses were 15 individuals. The results showed that thegrowth in length and weight milkfish seed from fry to young broodstock (size up to $500 \mathrm{~g}$ ) from Aceh and Bali was slightly higher than that of Gorontalo, but no significant differences $(P>0.05)$ were observed among the populations. The genetic analysis showed five haplotypes composite from four restriction enzymes i.e., M bo I, Hae III, Hha I, and Nla IV at on cytochrome-b sequen. The averagenumber of restriction site was 1-3 haplotypes. Aceh and Bali populations have lower genetic variations (0.080 and 0.000$)$ compared to Gorontalo $(0.115)$.

KEYWORDS: genetic; growth; milkfish; Chanos chanos; Indonesia

\section{PENDAHULUAN}

Ikan bandeng merupakan makanan yang sangat diminati di Asia Tenggara (Shiau, 2010). Budidaya bandeng tradisional pertama di mulai di Indonesia pada

\footnotetext{
* Korespondensi: Balai Besar Riset Budidaya Laut dan Penyuluhan Perikanan. J. Br. Gondol Kec. Gerokgak Kab. Buleleng, Po. Box 140, Singaraja 81155, Bali, Indonesia. Tel. + 6236292272

E-mail: moriasembiring@yahoo.co.id
}

tahun 1400-an (Bardach et al., 1972) diikuti oleh Filipina (Bagarinao, 1998) dan Taiwan (Chen \& Hsu, 2006). Sejak saat itu, dari beberapa hasil penelitian dan pengembangan telah menghasilkan teknik yang handal untuk budidaya ikan bandeng secara intensif (Bagarinao, 1998; Lee, 1998). Perkembangan permintaan benih bandeng hasil hatchery baik di dalam maupun luar negeri perlu diantisipasi untuk menjaga keberlanjutan usaha perbenihan yang ada, oleh karena 
itu, maka diperlukan terobosan dalam penyediaan benih unggul yang terjamin kualitasnya baik secara fenotipe maupun secara genotipe.

Dalam upaya penyediaan benih unggul, telah dilakukan program seleksi yang diawali dengan cara mengumpulkan benih-benih (nener) bandeng alam dari berbagai sumber penangkapan nener di perairan pantai di Timur Sumatera (Aceh), Sulawesi (Gorontalo), dan Bali. Tempat pengambilan benih tersebut dipilih berdasarkan potensinya sebagai sumber benih (nener) alam. Populasi benih ikan bandeng di alam dipengaruhi oleh arah arus. Pergerakan arus selatan dari Laut Arafura hingga ke Samudera Hindia dan pergerakan Laut Cina Selatan hingga Samudera Pasifik. Menurut Bakosurtanal (2012), terdapat pergerakan dua arus besar di Indonesia, yaitu pergerakan arus hangat di selatan dari Laut Arafura hingga ke Samudera Hindia, dan pergerakan arus hangat di Laut Cina Selatan hingga Samudera Pasifik juga sebal iknya. Arus hangat tersebut kaya akan bahan makanan sehingga rantai makanan menjadi kompleks. Hal inilah yang diduga benih bandeng alam terdapat di tiga perairan tersebut.

Beberapa studi yang berkaitan dengan struktur populasi bandeng telah dilaporkan (Winans, 1985; Ravago-Gotanco \& Juinio-Menez, 2004), menunjukkan bahwa karakter meristik dan morfometrik ikan bandeng dari lima belas lokasi di Samudera Pasifik (Kepulauan Filipina di bagian barat), sepanjang Samudera Pasifik Khatulistiwa termasuk Tahiti dan Kepulauan Hawaii, secara meristik tidak ada perbedaan ikan bandeng, namun secara morfometrik sampel dari Hawaii dan Samudera Pasifik umumnya memiliki bentuk kepala lebih besar dengan ukuran ekor yang lebih kecil dibandingkan dengan sampel dari Filipina. Sel anjutnya menurut Winans (1985), dari hasil struktur populasi genetik, menunjukkan bahwa populasi ikan bandeng di Samudera Pasifik tiga kelompok yang berbeda: Kepulauan Filipina; Samudera Pasifik Khatulistiwa, termasuk Tahiti dan Kepulauan Hawaii.

Dalam rangka pengembangan pembenihan ikan bandeng skala komersial dan berkelanjutan, maka informasi keragaman genetik populasi bandeng sangat dibutuhkan. Hal ini dikarenakan penurunan variasi genetik akan berdampak pada pertumbuhan, dan rentan terhadap serangan penyakit, serta perubahan lingkungan (Stringwell et al., 2014). Penurunan keragaman dapat terjadi menggunakan induk dalam jumlah yang terbatas dan berkerabat dekat akibat terjadinya peningkatan inbreeding yang berdampak performa (Christie et al., 2012; Fisch et al., 2015). Oleh karena itu, perlu dilakukan pengamatan variasi genetik dan pertumbuhan benih bandeng hingga menjadi calon induk dari lokasi yang berbeda. Tujuan dari penelitian ini adalah mendapatkan data pertumbuhan dan variasi genetik benih bandeng yang berasal dari lokasi perairan Aceh, Bali, dan Gorontalo sehingga diperoleh induk bandeng yang berkualitas.

\section{BAHAN DAN METODE}

\section{Hewan Uji}

Hewan uji pada penelitian ini berupa benih ikan bandeng, Chanos chanos hasil tangkapan dari alam di perairan Aceh, Bali, dan Gorontalo yang merupakan calon induk F-1. Rata-rata ukuran panjang dan bobot awal benih (nener) al am dari tiga lokasi perarian adalah $2,28 \pm 0,16 \mathrm{~cm} ; 0,27 \pm 0,01 \mathrm{~g}$.

Benih dipelihara di Instalasi Tambak Percobaan Balai Besar Riset Budidaya Laut dan Penyuluhan Perikanan. Sumber dan pergantian air dalam tambak percobaan berasal dari pasang surut, salinitas air tambak selama pelaksanaan percobaan berkisar antara 35-40 ppt (Tabel 1). Petakan tambak yang digunakan berukuran $8.100 \mathrm{~m}^{2}$ dan dibagi menjadi tiga bagian dengan menggunakan sekat ganda sehingga masing-masing memiliki luas $2.700 \mathrm{~m}^{2}$. Pada masing-masing luasan sekat, dibuat petak pendederan (kolam kecil) di dalam tambak dengan ukuran $10 \mathrm{~m} \times 10$ m untuk pembesaran nener sebelum dilepas ke dalam tambak.

Tambak diberi pupuk organik berupa kotoran ayam dengan jumlah 1 ton/ha. Setelah empat hari pemupukan, kemudian level air dinaikkan hingga 60 $\mathrm{cm}$ dan nener mulai ditebar. Jumlah nener yang ditebar dalam ipukan sebanyak 20.000 ekor lalu dipelihara selama 45 hari. Sebelum nener/benih dilepas dari ipukan ke tambak, sebanyak 15 ekor benih diambil untuk pengukuran pertumbuhan, selanjutnya pengambilan sampel dilakukan setiap bulan untuk menentukan laju pertumbuhan ketiga sumber benih yang digunakan dalam percobaan ini.

\section{Analisis Variasi Genetik Ikan Bandeng}

Karakter variasi genetik ikan bandeng dianalisis menggunakan penanda molekuler Restriction Fragment Length Polymorphism (RFLP) DNA. Tahapan analisis variasi genetik dengan penanda RFLP sebagai berikut:

\section{Ekstraksi dan Purifikasi Template DNA}

Materi DNA diambil dari keseluruhan tubuh sampel benih ikan bandeng, sedangkan pada calon induk diambil dari bagian daging. Ekstraksi DNA dilakukan dengan menggunakan 10\%Chelex-100 dalam TE buffer $\mathrm{pH}-8$ dan $7,0 \mu \mathrm{L}$ proteinase $\mathrm{K}(20 \mathrm{mg} / \mathrm{mL})$, diinkubasi selama 2,5 jam pada suhu $55^{\circ} \mathrm{C}$ dan delapan menit pada suhu $89^{\circ} \mathrm{C}$, serta disentrifugasi dengan kecepatan 13.000 rpm selama 10 menit. Genom DNA hasil 
Tabel 1. Nilai parameter kualitas air di tambak pemeliharan ikan bandeng, Chanos chanos Table 1. Water quality variations in the earthen ponds used for milkfish, Chanos chanos culture

\begin{tabular}{lcc}
\hline \multicolumn{1}{c}{ Parameter (Parameters) } & $\begin{array}{c}\text { Musim hujan (Januari-Juni) } \\
\text { Rainy season (January-June) }\end{array}$ & $\begin{array}{c}\text { Musim kemarau (Juli-Oktober) } \\
\text { Dry season (July-October) }\end{array}$ \\
\hline Salinitas (Salinity) (ppt) & $35-40$ & $60-67$ \\
Oksigen terlarut (Dissolved oxygen) (mg/L) & $4.56-5.86$ & $5.74-6.45$ \\
Suhu (Temperature) $\left({ }^{\circ} \mathrm{C}\right)$ & $28.3-29.4$ & $29.8-30.0$ \\
\hline
\end{tabular}

ekstraksi, dipurifikasi menggunakan kit Qiaquick purification (USB) dan prosedur purifikasi mengikuti manual dari kit tersebut.

\section{Amplifikasi mt-DNA}

Primer yang digunakan untuk mengamplifikasi genom DNA sampel ikan bandeng adalah primer cytochrome-b (F: 5'-ATG GCA AGC CTA CGA AAA ACC CAC C-3' dan R: 5'-GGC TCA TTC AAG GGC TTT GTT TTC G-3'). Amplifikasi DNA disesuaikan dengan kondisi PCR, yaitu satu siklus denaturasi pada suhu $95^{\circ} \mathrm{C}$ selama satu menit, 36 siklus pada $95^{\circ} \mathrm{C}$ selama 45 detik, 30 detik pada suhu annealing $66^{\circ} \mathrm{C}$ dan 45 detik pada $72^{\circ} \mathrm{C}$, selanjutnya satu siklus terakhir pada suhu $72^{\circ} \mathrm{C}$ selama lima menit. Untuk mengetahui pola pita tunggal yang dihasilkan dari amplifikasi PCR, maka digunakan agaros gel 1,5\%dalam Tris-Boric-EDTA (TBE) buffer dan diamati dengan transilluminator (UV), serta didokumentasikan dengan Gel-doc kamera.

\section{Restriction Fragment Length Polymorphism (RFLP)}

Untuk mengetahui variasi susunan nukleotida DNA antar po pulasi ikan bandeng, template DNA dari produk amplifikasi PCR dipotong dengan enzim restriksi M bo I, Hae III, Hha I, dan Nla IV. Hasil restriksi kemudian dipisahkan secara elektroforesis menggunakan agaros gel 2\%dalam Tris-Boric-EDTA (TBE) buffer pada $125 \mathrm{~mA}$ selama 40 menit dan diamati dengan transilluminator (UV).

\section{Analisis Data}

Data pertumbuhan panjang total dan bobot badan mulai dari benih hingga mencapai ukuran $500 \mathrm{~g}$ dari perairan yang berbeda disajikan dalam bentuk grafik. Untuk mengetahui adanya perbedaan pertambahan panjang dan bobot tersebut, dilakukan analisis secara statistik menggunakan software $R$ version 3.3.2. (Anova) pada selang kepercayaan 95\%

Keragaman genetik dianalisis dengan descriptive statistics, exact test for population differentiation (Raymond \& Rousset, 1995 dalam Miller, 1997) dengan menggunakan program TFPGA (Tools for Population
Genetic Analysis). Kekerabatan antar populasi berdasarkan jarak genetik dan dendrogram dianalisis menggunakan UPGMA (Unweighted Pair Group M ethod with Arithmetic M ean) Wright (1978) modifikasi Rogers (1972) dalam Miller (1997) dari software TFGPA.

\section{HASIL DAN BAHASAN}

\section{Performa Pertumbuhan Ikan Bandeng}

Keragaan pertumbuhan ikan bandeng melalui pengukuran panjang total dan bobot badan mulai dari benih alam hingga menjadi calon induk terlihat pada Gambar 1 dan 2.

Faktor yang memengaruhi terhadap adaptasi morfologi ikan bandeng dapat berupa kualitas air dan komposisi pakan yang diberikan. Benih ikan bandeng akan tumbuh lebih baik jika kondisi kulitas air di tambak dan kualitas pakan yang diberikan memadai sehingga dapat mendukung pertumbuhan benih tersebut. Pada tambak dengan salinitas tinggi (> 34 ppt) pada umumnya akan memberikan pertumbuhan ikan yang lambat dibandingkan salinitas payau (15-20 ppt) (Biswas et al., 2011). Hasil pengamatan pada pertumbuhan benih ikan bandeng asal Aceh, Gorontalo, dan Bali memiliki pola yang cenderung berbeda. Tiga bulan awal pemeliharaan pertumbuhan benih bandeng asal Gorontalo memiliki kecepatan tumbuh yang jauh lebih tinggi bila dibandingkan dengan benih bandeng asal Aceh maupun Bali. Namun pada saat musim kemarau dengan suhu perairan berkisar antara $29^{\circ} \mathrm{C}-34^{\circ} \mathrm{C}$ dan salinitas mencapai > 50 ppt (Tabel 1), bobot benih dari Aceh dan Bali tidak mengalami penurunan dibandingkan dengan benih asal Gorontalo, ini diduga karena benih dari Bali dan Aceh sudah beradaptasi terhadap kondisi air di tambak. Di samping itu, juga dilihat dari nilai variasi genetik pada benih dari Aceh dan Bali lebih kecil dibandingkan dengan benih dari Gorontalo (Tabel 2). Menurut Dunham (2011) dan Bernatchez (2016), keragaman genetik memengaruhi kemampuan spesies untuk merespons perubahan lingkungan baik buatan maupun alami dalam proses adaptasi agar bertahan hidup. Populasi dengan keragaman genetik yang tinggi memiliki peluang hidup 


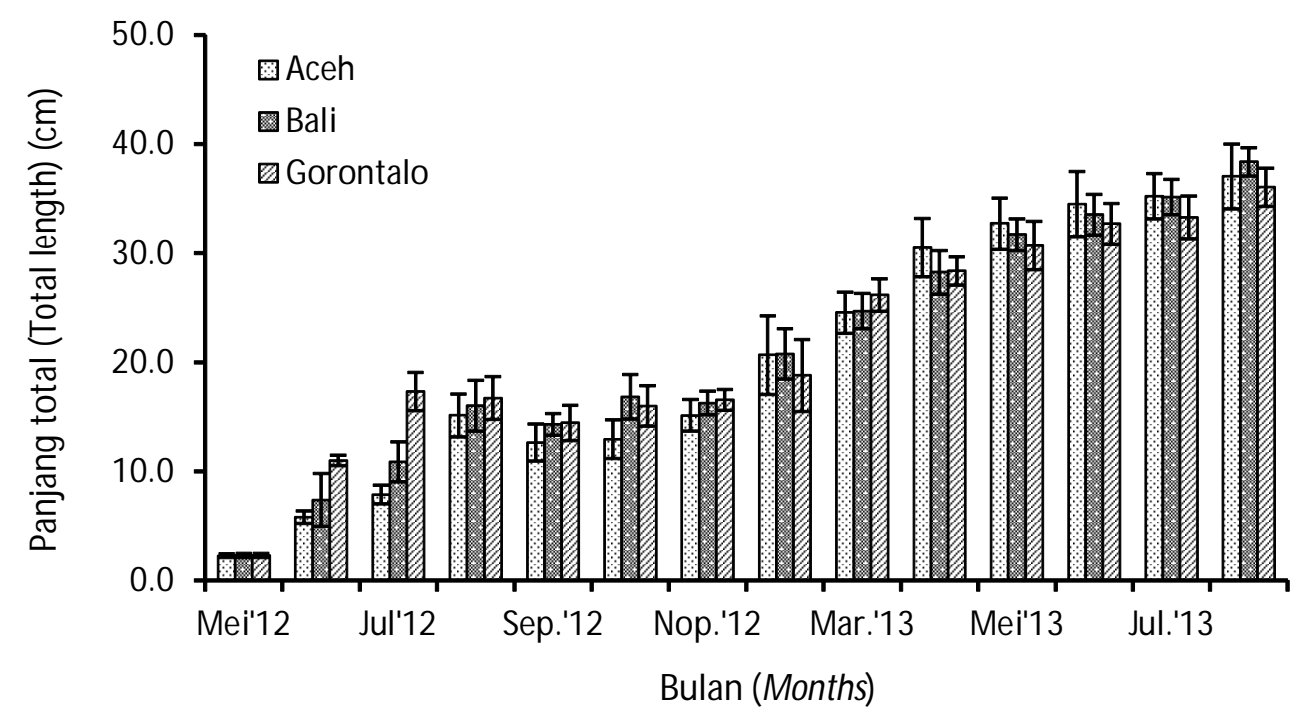

Gambar 1. Pertumbuhan panjang total ikan bandeng, Chanos chanos dari lokasi perairan Aceh, Bali, dan Gorontalo.

Figure 1. Growth in total length of milkfish, Chanos chanos from Aceh, Bali, and Gorontalo Waters.

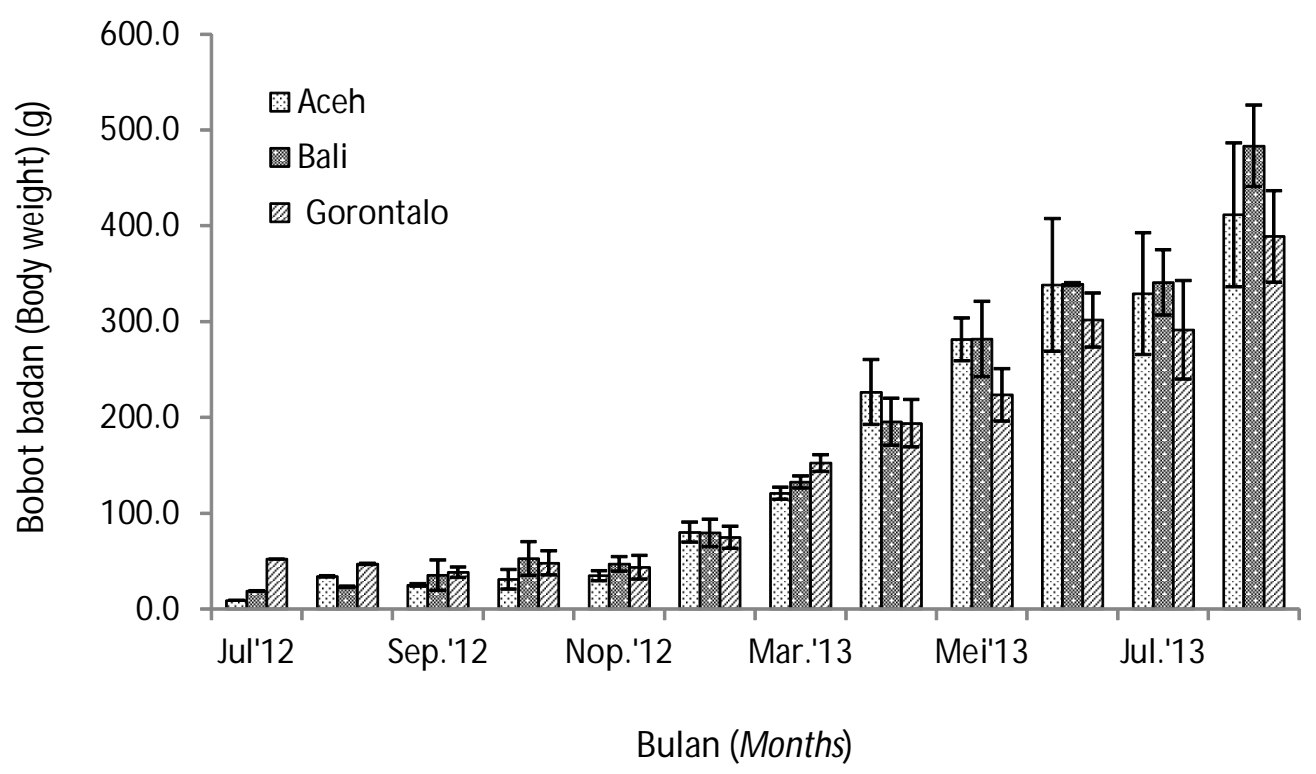

Gambar 2. Pertumbuhan bobot badan ikan bandeng, Chanos chanos dari lokasi perairan Aceh, Bali, dan Gorontalo.

Figure 2. Growth in body weight of milkfish, Chanos chanos from Aceh, Bali, and Gorontalo Waters.

yang lebih tinggi, karena banyak alternatif gen atau kombinasi gen yang tersedia untuk merespons perubahan kondisi lingkungan yang dihadapi.

Tave (1994) dan Soewardi (2007), menyatakan bahwa karakter fenotipe seperti panjang, bobot, dan kecepatan tumbuh dipengaruhi oleh faktor genetik dan interaksinya. Hal ini juga terjadi pada benih bandeng alam dari lokasi yang berbeda. Kondisi tambak BBRBLPP Gondol di musim kemarau, saat salinitas tinggi sangat memengaruhi pertumbuhan yang berkaitan dengan perangsangan makan maupun osmoregulasi. Menurut Lisboa et al. (2015), sebagian besar hewan laut tipe osmoregulator-eurihalin, pengaruh langsung dari salinitas media pemeliharaan adalah melalui efek osmotiknya, ikan hanya akan mempertahankan keseimbangan terhadap 
osmoregulasi dan kemampuan untuk mencerna pakan. Pada salinitas tinggi, energi yang diperoleh dari kecernaan pakan hanya digunakan untuk mempertahankan osmoregulasi, sehingga pembentukan jaringan otot untuk pertumbuhan tidak optimum (Castillo-Vargasmachuca et al., 2013).

\section{Variasi Genetik Ikan Bandeng}

Susunan nukleotida DNA pada cytochrome-b region ikan bandeng hasil amplifikasi PCR mempunyai panjang molekul sekitar 1.200 bp. Dari empat enzim restriksi ( $\mathrm{M}$ bo I, HaellI, Hha I, dan Nla IV) yang digunakan untuk pemotongan sekuens DNA hasil amplifikasi PCR ternyata pola polimorfisme didapatkan hanya pada enzim restriksi M bo I, Hae III, dan Nla IV, sedangkan Hha I bersifat monomorfisme. Satu di antara pola polimorfisme enzim restriksi M bo I tercantum pada Gambar 3. Secara statistik dengan menggunakan ANOVA menunjukkan bahwa terdapat perbedaan genetik secara nyata $(P<0,05)$ antara populasi benih ikan bandeng yang diuji Aceh, Bali, dan Gorontalo berdasarkan pada haplotipenya (Tabel 2).

Secara keseluruhan terdapat lima komposit haplotipe yang diidentifikasi berdasarkan empat jenis enzim restriksi pada DNA cytochrome-b region ikan bandeng yang diamati. Jumlah komposit haplotipe yang dimiliki oleh masing-masing ikan bandeng uji berkisar antara 1-3. Jumlah yang terkecil diamati pada bandeng dari Aceh, sedangkan yang tertinggi bandeng dari Go rontalo. Terlihat bahwa bandeng dari Gorontalo didominasi oleh komposit haplotipe 1, 4, dan 5, sedangkan bandeng dari Bali lebih didominasi oleh komposit haplotipe 1, 4; dan Aceh oleh komposit haplotipe 1, 3. Secara keseluruhan ikan bandeng yang diuji mempunyai komposit haplotipe-1 (Tabel 2).

Nilai diversitas haplotipe benih ikan bandeng dari perairan Aceh dan Bali tidak berbeda nyata yaitu sebesar 0,031; sementara nilai diversitas haplotipe sebesar 0,089 terdapat pada benih ikan bandeng dari perairan Gorontalo. Hal yang sama terlihat pada calon induk bandeng, mempunyai nilai diversitas haplotipe sebesar 0,080 pada calon induk ikan bandeng dari perairan Aceh dan 0,115 pada calon induk ikan bandeng dari Gorontalo. Hasil analisis tidak memberikan nilai diversitas haplotipe pada calon induk bandeng dari perairan Bali.

Secara umum, keseluruhan populasi ikan bandeng (benih dan calon induk) yang diuji mempunyai komposit haplotipe utama yang serupa. Ini menandakan bahwa ada kemungkinan ikan tersebut mempunyai sumber genetik yang sama. Haplotipe-1 (AAAA) dapat terlihat dari frekuensi yang besar pada setiap populasi, baik pada populasi benih maupun calon induk ikan bandeng. Frekuensi haplotipe-2 (ABAA) relatif rendah dan hanya terdapat pada benih dari perairan Aceh dan Bali $(6,7 \%$; sedangkan haplotipe-3 (AAAB), frekuensi lebih rendah dan hanya terdapat pada calon induk bandeng dari Aceh. Pada haplotipe-4 (AAAC) terlihat adanya frekuensi sebesar 13,3\% pada benih ikan bandeng dari Gorontalo, sedangkan pada calon induk (Gorontalo) mempunyai haplotipe-4 (AAAC) dan 5 (AAAD) masing-masing dengan frekuensi (10\%) dan 20\% Satu hal yang mungkin menjadi penyebab fenomena ini adalah adanya penyisipan sifat/genetic introgression pada ketiga populasi benih dan calon induk ikan bandeng tersebut.

Nilai diversitas haplotipe populasi benih bandeng dari perairan Aceh dan Bali lebih rendah dibandingkan dengan benih dari Gorontalo. Rendahnya nilai diversitas haplotipe benih dari Aceh dan Bali, diduga selain karena benih nener dari Bali dan Aceh berasal hasil perbenihan di hatchery yang lepas ke alam, juga dalam proses mencari makanan, ikan bandeng yang hidup di laut lepas sekitar Aceh dan Bali cenderung mengarah ke Samudera Hindia mengikuti pergerakan arus air hangat, sedangkan ikan bandeng yang terdapat

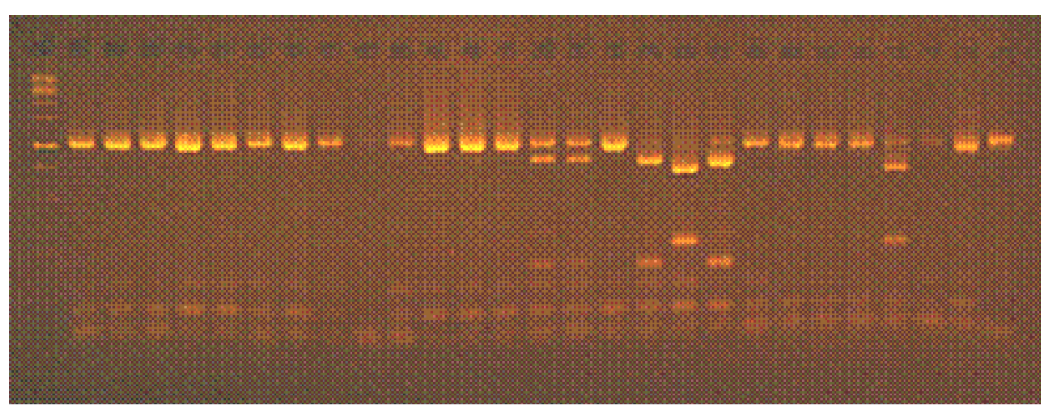

Gambar 3. Pola restriksi dari produk amplifikasi DNA ikan bandeng, Chanos chanos menggunakan enzim Mbo I.

Figure 3. Restriction pattern of DNA amplification product of milkfish, Chanos chanos digested using Mbo I enzyme. 
Tabel 2. Distribusi frekuensi haplotipe ikan bandeng, Chanos chanos berdasarkan cytochrome-b yang direstriksi dengan menggunakan empat lokus enzim, M bo I, Hae III, Hha I, dan Nla IV

Table 2. Frequency distribution of haplotype of milkfish, Chanos chanos based on cytochrome-b and was restricted by four loci enzyme, Mbo I, Hae III, Hha I, and Nla IV

\begin{tabular}{|c|c|c|c|c|c|c|}
\hline \multirow{3}{*}{$\begin{array}{l}\text { Haplotipe } \\
\text { Haplotype }\end{array}$} & \multicolumn{6}{|c|}{ Provinsi (Province) } \\
\hline & \multicolumn{2}{|r|}{ Aceh } & \multicolumn{2}{|r|}{ Bali } & \multicolumn{2}{|r|}{ Gorontalo } \\
\hline & $\begin{array}{c}\text { Benih } \\
\text { Fingerling }\end{array}$ & $\begin{array}{c}\text { Calon induk } \\
\text { Young broodstock }\end{array}$ & $\begin{array}{c}\text { Benih } \\
\text { Fingerling }\end{array}$ & $\begin{array}{c}\text { Calon induk } \\
\text { Young broodstock }\end{array}$ & $\begin{array}{c}\text { Benih } \\
\text { Fingerling }\end{array}$ & $\begin{array}{c}\text { Calon induk } \\
\text { Young broodstock }\end{array}$ \\
\hline AAAA & 0.933 & 0.800 & 0.933 & 1,000 & 0.867 & 0.700 \\
\hline ABAA & 0.067 & 0.000 & 0.067 & 0.000 & 0.000 & 0.000 \\
\hline AAAB & 0.000 & 0.200 & 0.000 & 0.000 & 0.000 & 0.000 \\
\hline AAAC & 0.000 & 0.000 & 0.000 & 0.000 & 0.133 & 0.100 \\
\hline AAAD & 0.000 & 0.000 & 0.000 & 0.000 & 0.000 & 0.200 \\
\hline $\mathrm{N}$-sampel (N-sample) & 15 & 10 & 15 & 10 & 15 & 10 \\
\hline N-haplotipe (N-haplotype) & 2 & 2 & 2 & 1 & 2 & 3 \\
\hline Diversitas genetik (Gene diversity) & $0.031^{a}$ & 0.080 & $0.031^{\mathrm{a}}$ & 0 & $0.089^{b}$ & 0.115 \\
\hline
\end{tabular}

di Gorontalo akan lebih mudah menjangkau Samudera Pasifik maupun Laut Cina Selatan. Pergerakan mencari makan di Samudera Hindia akan membuat membuat pola migrasi yang beraturan dalam rentang waktu yang lama sehingga terdapat kemiripan bahkan kesamaan antara populasi ikan bandeng Aceh dan Bali.

Jarak genetik yang dihitung menurut Nei (1978), berdasarkan situs restriksi dari empat enzim restriksi secara komputasi dengan program TFPGA antara populasi benih bandengdari tiga lokasi tertera pada Tabel 3.

Berdasarkan perhitungan jarak genetik dari tiga populasi benih bandeng diperoleh nilai jarak genetik terdekat adalah antara populasi Aceh dan Bali yaitu sebesar 0,0010; kemudian antara populasi Aceh dengan populasi Gorontalo yaitu 0,0047. Sedangkan jarak paling jauh adalah jarak genetik antara populasi Bali dengan populasi dari Gorontalo dengan jarak genetik sekitar 0,0066.

Dendogram yang dibentuk berdasarkan jarak genetik tersebut dengan menggunakan program
Unweighted Pair Group Arithmatic Average (UPGMA) menunjukkan bahwa antara populasi benih bandeng dari perairan Aceh dan Bali mempunyai kekerabatan yang lebih dekat dibandingkan dengan kekerabatan antara keduanya dengan benih bandeng dari Gorontalo (Gambar 4).

Berdasarkan dendogram (Gambar 4), kedekatan jarak genetik antara populasi benih bandeng dari perairan Aceh dan Bali, mungkin selain disebabkan oleh genetic introgression melalui berbagai cara (perdagangan) benih bandeng tersebut masuk ke perairan Aceh atau sebaliknya, dan akhirnya akan terjadi perkembangbiakan populasi, juga dipengaruhi oleh faktor arus laut. Hal ini terlihat dari beberapa hasil penelitian menunjukkan bahwa variasi habitat, tingkah laku larva, durasi tahap pelagis, dan topografi telah terbukti menjadi hambatan utama terhadap aliran gen pada berberapa spesies lain (Wiadnya et al., 2015; Takamura \& Nakahara, 2015).

Pemilik hatcheri bandeng menggunakan sumber induk dari pembudidaya di lokasi lain dengan

Tabel 3. Jarak genetik Nei antara benih ikan bandeng, Chanos chanos dari perairan Aceh, Bali, dan Gorontalo

Table 3. Nei genetic distance among milkfish, Chanos chanos fingerling collected from Aceh, Bali, and Gorontalo waters

\begin{tabular}{lccc}
\hline & Aceh & Bali & Gorontalo \\
\hline Aceh & $====$ & 0.0010 & 0.0047 \\
Bali & & $====$ & 0.0066 \\
Gorontalo & & & $====$ \\
\hline
\end{tabular}




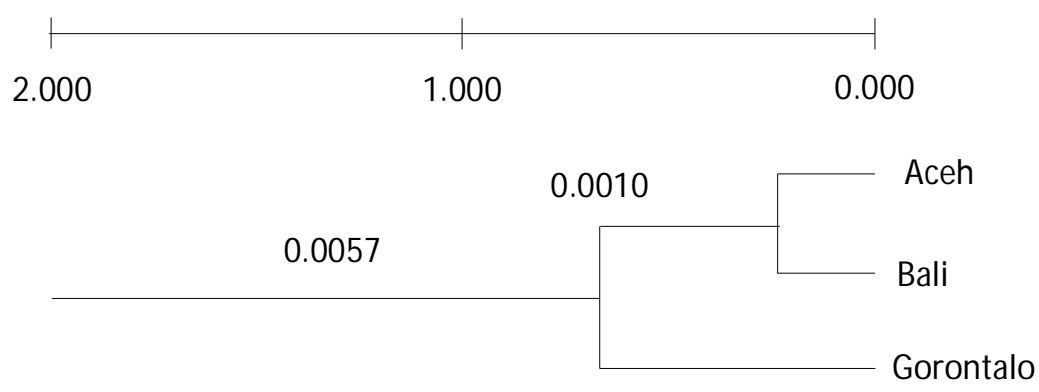

Gambar 4. Dendogram benih bandeng, Chanos chanos dari perairan Aceh, Bali, dan Gorontalo.

Figure 4. Dendogram of milkfish, Chanos chanos fingerling collected from Aceh, Bali, and Gorontalo waters.

informasi genetik yang terbatas, serta jumlah induk yang sedikit (Sudradjat \& Sugama, 2010). Proses pembenihan yang demikian ini, cenderung menyebabkan hilangnya variasi genetik yang lebih tinggi (genetik drift dan efek inbreeding) (Yu et al., 2012; O'Leary et al., 2013), terutama pada ikan bandeng yang mempunyai fekunditas tinggi sehingga untuk memproduksi telur cenderung menggunakan jumlah induk yang lebih sedikit dalam memenuhi target produksi. Dari informasi keragaman genetik tersebut dapat digunakan sebagai acuan penggunaan induk bandeng untuk pemuliaan dan pembenihan agar diperoleh benih yang berkualitas. Informasi yang diperoleh untuk merancang program pengelolaan induk ikan bandeng (broodstock management) jangka panjang seperti perbaikan genetik dengan program selektif breeding.

\section{KESIMPULAN DAN SARAN}

Pertumbuhan calon induk yang bersumber dari tiga lokasi tidak berbeda nyata. Variasi genetik populasi calon induk bandeng dari benih asal Gorontalo mempunyai nilai tertinggi $(0,115)$ dikuti dengan populasi Aceh $(0,080)$; dan Bali $(0,000)$. Populasi benih dan calon induk dari perairan Aceh dan Bali mempunyai pasangan alel yang hampir sama dengan jarak genetik yang dekat $(0,0010)$ sedangkan populasi Gorontalo mempunyai jarak yang genetik paling jauh $(0,0057)$ terhadap dua populasi lainnya.

Kajian lebih lanjut perlu dilakukan untuk melihat keragaman genetik benih hasil penggabungan induk yang berasal dari Provinsi Aceh, Bali, dan Gorontalo tersebut untuk mendukung produksi benih unggul.

\section{UCAPAN TERIMA KASIH}

Ucapan terima kasih yang sebesar-besarnya terhadap DIPA Balai Besar Penelitian dan Pengembangan Budidaya Laut Gondo I Tahun Anggaran 2014 yang telah membiaya kegiatan penelitian ini.

\section{DAFTAR ACUAN}

Bagarinao, T. (1998). Historical and current trends in milkfish farming in the Philippines. Academic Press, San Diego. In: Trop. Mariculture, p. 381-422.

Bakosurtanal. (2012). Atlas Nasional Indonesia. http:/ /bakosurtanal.go.id. Diakses tanggal 6 Desember 2012 pukul 09.40 BTWI.

Bardach, J.E., Ryther, J.H., \& McLarney, W.O. (1972). Milkfish culture. John Wiley \& Sons, Toronto. In: Aquacult. Farming Husbandry Freshwater Marine Organisms, p. 313-349.

Bernatchez, L. (2016). On the maintenance of genetic variation and adaptation to environmental change: considerations from population genomics in fishes. Journal of Fish Biology, 89, 2519-2556.

Biswas, G., Sundaray, J.K., Thirunavukkarasu, A.R., \& Kailasam, M. (2011). Length-weight relationship and variation in condition of Chanos chanos (Forsskal, 1775) from tide-fed brackishwater ponds of the Sunderbans - India. Indian Journal of Geo-marine Science, 40(3), 386-390.

Castillo-Vargasmachuca, S., Ponce-Palafox, J.T., Rodriguez-Chavez, G., Arredondo-Figueroa, J.L., Chavez-Ortiz, E., \& Seidavi, A. (2013). Effects of temperature and salinity on growth and survival of the Pacific red snapper Lutjanus peru (Pisces: Lutjanidae) juvenile. Lat. Am. J. Aquat. Res., 41(5), 1013-1018.

Chen, Y.C., \& Hsu, C.Y. (2006). Ecological considerations of cage aquaculture in Taiwan. J. Fish. Soc. Taiwan, 33, 139-146.

Christie, M., Marine, M., French, R., Waples, R., \& Blouin, M.S. (2012). Effective size of a wild salmonid population is greatly reduced by hatchery supplementation. Heredity, 109, 254-260.

Dunham, R.A. (2011). Aquaculture and fisheries biotechnology: Genetic approaches. $2^{\text {nd }}$ Edition. Cambridge, US: CABI Publishing. 
Fisch, K.M., Kozfkay, C.C., Ivy, J.J., Ryder, O.A., \& Waples, R.S. (2015). Fish hatchery genetic management techniques: integrating theory with implementation. North American Journal of Aquaculture, 77, 343-357.

Lee, C.S. (1998). Culture of marine finfish species of the Pacific. Academic Press, San Diego. In: Trop. Mariculture, p. 361-380.

Lisboa, V., Barcarolli, I.F., Sampaio, L.A., \& Bianchini, A. (2015). Effect of salinity on survival, growth and biochemical parameters in juvenile Lebranch mullet Mugil liza (Perciformes: Mugilidae). Neotropical Ichthyology, 13(2), 447-452.

Miller, M.P. (1997). Tools for po pulation genetic analyses (TFPGA) [Documentation file]. Available with the program's installation files at http://www. marksgeneticsoftware. net/ tfpga.htm.

Nei, M. (1978). Estimation of average heterozygosity and genetic distance from a small number of individuals. Genetics, 85, 583-590.

O'Leary, S.J., Hice, L.A., Feldheim, K.A., Frisk, M.G., McElroy, A.E., Fast, M.D., \& Chapman, D.D. (2013). Severe inbreeding and small effective number of breeders in a formerly abundant marine fish. Published online 2013 June 7. doi: 10.1371/ journal.pone.0066126.

Ravago-Gotanco, R.G., \& Juinio-Menez, M.A. (2004). Population genetic structure of the milkfish, Chanos chanos, based on PCR-RFLP analysis of the mitochondrial control region. Mar. Biol., 145, 789-801.

Shiau, C.Y. (2010). Biochemical characteristics of milkfish (Chanos chanos). National Taiwan Ocean University, The Fisheries Society of Taiwan, Asian Fisheries Society, World Aquaculture Society, Keelung. In: M ilkfish Aquaculture in Asia, p. 157-167.
Soweardi, K. (2007). Pengelolaan kergaman genetik sumberdaya perikanan dan kelautan. Departemen Manajemen Sumberdaya Perairan, Institut Pertanian Bogor. Bogor, $153 \mathrm{hlm}$.

Sudradjat, A., \& Sugama, K. (2010). Aquaculture of milkfish (bandeng) in Indonesia: fry and fingerling production. National Taiwan Ocean University. The Fisheries Society of Taiwan, Asian Fisheries Society, World Aquaculture Society, Keelung. In: Milkfish Aquaculture in Asia, p. 9-16.

Stringwell, R., Lock, A., Stutchbury, C.J., Baggett, E., Taylor, J., Gough, P.J., \& Garcia de Leaniz, C. (2014). Maladaptation and phenotypic mismatch in hatchery-reared Atlantic salmon Salmo salar realeased in the wild. J. of Fish Biol., 85, 1927-1945.

Takamura, K., \& Nakahara, M. (2015). Intraspesific invasion occurring in geographically isolated populations of the Japanese cyprinid fish Zacco platypus. Limnology, 16(3), 161-170.

Tave, D. (1994). Selective breeding programs for medium-sized fish farm. Rome: FAO Fisheries Technical paper, $122 \mathrm{pp}$.

Wiadnya, D.G.R., Widodo, Setyohadi, D., \& Soemarno. (2015). Intra-species variations of Photopectoralis bindus (Family: Leiognathidae) collected from two geographical areas in East Java, Indonesia. Journal of Biodiversity and Environmental Sciences, 6(1), 160-168.

Winans, G.A. (1985). Geographic variation in milkfish Chanos chanos. II. Multivariate morphological evidence. Copeia, 4, 890-989.

Yu, Z.N., Azuma, N., \& Abe, S. (2012). Genetic differentiation between collections of hatchery and wild masu salmon (Oncorhyncus masou) inferred from mitochondrial and microsatellite DNA analyses. Environ. Biol. Fish, 94, 259-271. 